\title{
Computerized Tomography Findings of Neutropenic Enterocolitis and Its Relationship With Prognosis
}

\author{
Nötropenik Enterokolitin Bilgisayarlı Tomografi Bulguları Ve Prognozla Ilişkisi
}

\author{
Ali Mahir Gündüz ${ }^{\star}$, Nurşen Toprak \\ Van Yüzüncü Yıl Üniversitesi Tıp Fakültesi Radyoloji Bölümü
}

\begin{abstract}
Objective: Neutropenic Enterocolitis (NE) is a serious complication characterized by transmural inflammation of the large and small intestines, with especially the cecum. The diagnosis of $\mathrm{NE}$ is usually based on a combination of clinical and radiological findings, and the most reliable method in diagnosis is computed tomography (CT).

In this study, we wanted to investigate which intestinal segments are affected in 15 patients we diagnose NE with CT and whether there is a relationship between intestinal involvement and prognosis.

Materials and Methods: After the CTs of all patients were examined in detail, they were divided into groups according to the intestinal segments held. Then, by measuring the size of the intestinal wall where it is the thickest, it was investigated whether there is a relationship between intestinal involvement and prognosis.

Results: We detected an increase in mucosal enhancement and wall thicknesses of at least $11 \mathrm{~mm}$ in the terminal ileum and other intestinal segments, primarily in the cecum and the ascending colon. The mesentery adjacent to the thickened intestinal segments had inflammatory contaminationheterogeneity and secondary mesenteric stranding, some local lymphadenopathies (LAPs), and free fluid appearance.

Conclusion: As a result, we obtained detailed information in determining intestinal involvement, the length of the affected intestine segment and mesenteric involvement with contrasted abdominal CT. Assuming that the cecum and right colon are affected in almost all cases, we found that additionally terminal ileum involvement is more likely to affect the prognosis than the additional left colon involvement.
\end{abstract}

Key Words: Computerized tomography, ileocecal involvement, neutropenic enterocolitis

\section{Introduction}

Neutropenic Enterocolitis (NE) is a serious complication characterized by transmural inflammation of the large and small intestines, mainly cecum. It is characterized by the development of ulceration, necrosis and perforation in the intestinal

\section{ÖZET}

Amaç: Nötropenik enterokolit (NE), başta çekum olmak üzere kalın ve ince bağırsakların transmural inflamasyonu ile karakterize ciddi bir komplikasyondur. NE tanısı genellikle klinik ve radyolojik bulguların bir kombinasyonuna dayanmakta olup tanıda en güvenilir yöntem bilgisayarlı tomografi (BT)'dir.

Bu çalışmada BT ile NE tanısı koyduğumuz 15 hastada hangi bağırsak segmentlerinin etkilendiğini ve bağırsak tutulumu ile prognoz arasında bir ilişki olup olmadığını araştırmak istedik.

Gereçler ve Yöntem: Tüm hastaların BT'leri detaylı bir şekilde incelendikten sonra tutulan bağırsak segmentlerine göre gruplara ayrıldı. Daha sonra en kalın olduğu yerdeki bağırsak duvarının boyutu ölçülerek bağırsak tutulumu ile prognoz arasında bir ilişki olup olmadığı araştırıldı.

Bulgular: Başta çekum ve çıkan kolon olmak üzere terminal ileum ve diğer bağırsak segmentlerinde en az 11 $\mathrm{mm}$ olan cidar kalınlaşmaları ve mukozal kontrastlanmada artış saptadık. Kalınlaşmış bağırsak segmentlerine komşu mezenterde enflamatuvar kirlenmeheterojenite ve buna sekonder mezenterik stranding, yer yer LAP'lar ve serbest sıvı görünümleri mevcuttu.

Tartışma: Sonuç olarak kontrastlı abdomen BT ile bağırsak tutulumunu saptamada, yaygınlığını belirlenmede ve mezenterik tutulumda detaylı bilgiler elde ettik. Çekum ve sağ kolonun hemen hemen tüm durumlarda etkilendiğini varsayarsak ilave sol kolon tutulumundansa ilave terminal ileum tutulumunun prognozu etkileme ihtimalini daha yüksek bulduk.

Anahtar Kelimeler: Bilgisayarlı tomografi, ileoçekal tutulum, nötropenik enterokolit

segment. NE is also called "typhlitis", and "ileocecal syndrome", and it is an acute condition that can progress quite mortally if not treated effectively $(1,2)$. Neutropenia is the main risk factor for the development of NE, and NE is most common in patients with hematological malignancies with neutropenia. These patients are thought to develop 
this condition through the translocation of bacteria along the weakened, fragile intestinal mucosa, which has been damaged by cytotoxic chemotherapy $(3,4)$. NE can also develop after multiple myeloma, aplastic anemia, acquired immunodeficiency syndrome, lymphoma, cyclic neutropenia, and solid organ transplantation $(5,6)$. The clinical picture is the presence of ileocolonic inflammation in patients with neutropenia, fever and abdominal pain. Since there are many diseases whose clinical features are similar to NE, other possible diagnoses should be excluded. Pseudomembranous colitis, acute appendicitis, appendix abscess, ischemic colitis, mesenteric lymphadenitis, inflammatory bowel disease and infectious colitis can be stated as some of these diseases $(7,8)$.

Although histological examination is the gold standard in the diagnosis of NE, patients generally do not allow endoscopic examination and surgical intervention because they are in critical condition (9). In addition, colonoscopy is contraindicated in patients with NE due to the risk of intestinal perforation (7). The diagnosis of NE is usually based on a combination of clinical and radiological findings. Direct radiography and ultrasonography (US) findings are nonspecific for the diagnosis of $\mathrm{NE}$, and computed tomography (CT) is the most reliable method in the diagnosis of NE. It is much more possible and easier to detect all radiological findings that can be seen in the course of NE, especially intestinal wall thickening, by CT compared to other methods. In neutropenic patients presenting with fever and abdominal pain, diagnosis is made by detecting characteristic CT findings (8). Treatment consists of IV antibiotics in addition to supportive therapy. Supportive measures are mainly intestinal rest through decompression by nasogastric probe, IV fluids, and parenteral nutrition, if required (10). Surgery may be required in patients who do not improve despite medical treatment, and whose condition worsens, or complications develop (intestinal perforation, abscess, pneumoperitoneum, gastrointestinal bleeding, etc.) (11).

In this study, we wanted to investigate which intestinal segments are affected in patients we diagnose NE with CT and whether there is a relationship between intestinal involvement and prognosis.

\section{Materials and Methods}

Our retrospective study was carried out according to the World Helsinki Declaration and was approved by the local ethics committee. The informed consent form was obtained from the patients or their relatives.
Abdominal CT of 15 patients were evaluated in detail. The affected intestinal segments were identified and grouped as follows:

Group A (only right colon involvement): Cecum and ascending colon involvement. In addition, intestinal involvements up to the hepatic flexure and the right half of transverse colon are also included in this group.

Group B (right colon and left colon involvement): In addition to Group A, one or more of the left colon segments (transverse colon left half, splenic flexura, descending colon, sigmoid colon and rectum) are affected.

Group C (right colon and terminal ileum involvement): In addition to Group $A$, the involment of terminal ileum.

Group D (right colon, left colon and terminal ileum involvement): In addition to Group B, the involment of terminal ileum.

Then, the size of the intestinal wall where it was the thickest was measured. Also, contaminationheterogeneity, lymphadenopathy (LAP) and free fluid findings in the surrounding mesentery were recorded as additional findings. Finally, the presence of primary disease, therapies applied, and the prognosis of the patients were investigated from the hospital records.

All contrast-enhanced abdominal CT images were performed with 128 slice CT [Siemens Definition AS + (Plus) Siemens AG, Munich, Germany] devices. On the CT image, the thickness of the section was $3 \mathrm{~mm}$ and the non-ionic contrast medium was applied as IV by an average flow of $2 \mathrm{~mL} / \mathrm{s}$.

Patients who did not show signs of NE on CT were excluded from the study.

Statistical Analysis: Descriptive statistics for the continuous variables were presented as Mean, Standard deviation, minimum and maximum values while count and percentages for categorical variables. Mann-Whitney $\mathrm{U}$ test was used to compare the group of living and dying patients. Chi-square test was performed to determine the relationship between categorical variables. Statistical significance level was considered as 5\% and SPSS (ver: 20) statistical program was used for all statistical computations.

\section{Results}

A total of 15 patients, 3 of whom were children, who were diagnosed with NE using contrast-enhanced abdominal CT, were included in the study. The patient group was between 1-64 years of age (mean age 38.5), where 5 of them were females and 10 were males. Five patients had acute myeloid leukemia 
Figure 1-4. In the contrast-enhanced abdominal CT examination of 17-year-old patient with acute lymphoblastic leukemia, the following findings are compatible with NE;

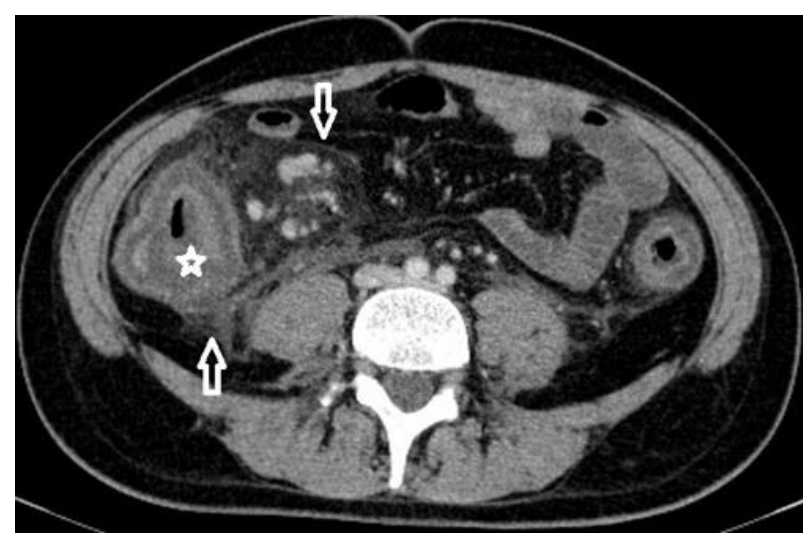

Fig. 1. In axial image, wall thickening in the cecum (star), adjacent mesentery contamination and secondary fat stranding, lymphadenopathy and free fluid observed (arrows)

(AML), 6 had acute lymphoblastic leukemia (ALL), 2 had lymphoma, 1 had lung cancer (Ca), 1 had stomach cancer, and all patients had a history of chemotherapy. A total of 9 patients, 6 males and 3 females, deceased, including one child (9/15: 60\%). Of the exitus patients 8 had leukemia (8/9: 89\%) (5 AML, 3 ALL), one had lung cancer (1/9: 11\%). The average age is 45.67 in exitus patients, 27.83 in surviving patients, and mortality increases as the age progresses. This increase was not statistically significant due to the low number of patients.

The main CT findings observed in patients with whom we diagnosed NE are as follows:

- We detected an increase in mucosal enhancement and wall thicknesses of at least $11 \mathrm{~mm}$ in the terminal ileum and other intestinal segments, primarily in the cecum and the ascending colon (Figures 1,2). Cecum and ascending colon involvement were present in all patients.

- The mesentery adjacent to the thickened intestinal segments had inflammatory contamination-heterogeneity and secondary mesenteric stranding, some local LAPs, and free fluid appearance (Figures 3,4). Mesenteric contaminationheterogeneity was observed in all of the patients, LAP was observed in 11 patients, and free fluid in 8 patients. Patient grouping according to patient information and bowel involvement is shown in table 1. Accordingly, the number of mortality in patients with only right colon involvement (group A) is 3 . The total of $\mathrm{B}$ and $\mathrm{D}$ groups shows the

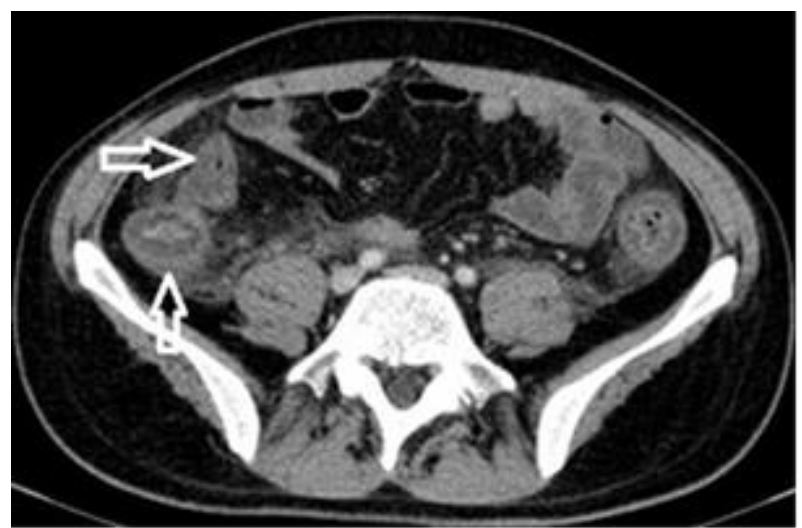

Fig. 2. Axial image shows wall thickening in the cecum (vertical arrow) and terminal ileum (horizontal arrow)

number of patients with additional left colon involvement, and here the number of exitus patients is 2. The total of $\mathrm{C}$ and $\mathrm{D}$ groups shows the number of patients with additional terminal ileum involvement, and here the number of exitus patients is 6 . In other words, the mortality rate in patients with additional terminal ileum involvement is higher than in patients with additional left colon involvement. However, due to the small number of cases, this difference was not statistically significant $(\mathrm{p}=0.580)$.

The average intestinal wall thickness detected in CT examinations was $20 \mathrm{~mm}$ and the difference between surviving and exitus patients was found statistically significant $(\mathrm{p}=0.018)$ (Table 2).

\section{Discussion}

NE was first identified in 1960 in patients with leukemia by Bierman and Amronin. These patients had inflammation and/or necrosis in the cecum, appendix and/or ileum, and they named it the ileocecal syndrome (12). This complication, which usually develops due to chemotherapeutics used in treatment during the course of malignant disease, may also develop depending on the primary disease itself $(13,14)$.

The effectiveness of radiological imaging methods used in the diagnosis of NE is as follows. Direct radiography is useful for detecting free air. Intraabdominal free air and local pneumatosis coli are rarely seen. Diffuse distention in the cecum, mass appearance and thumbprinting symptoms due to 


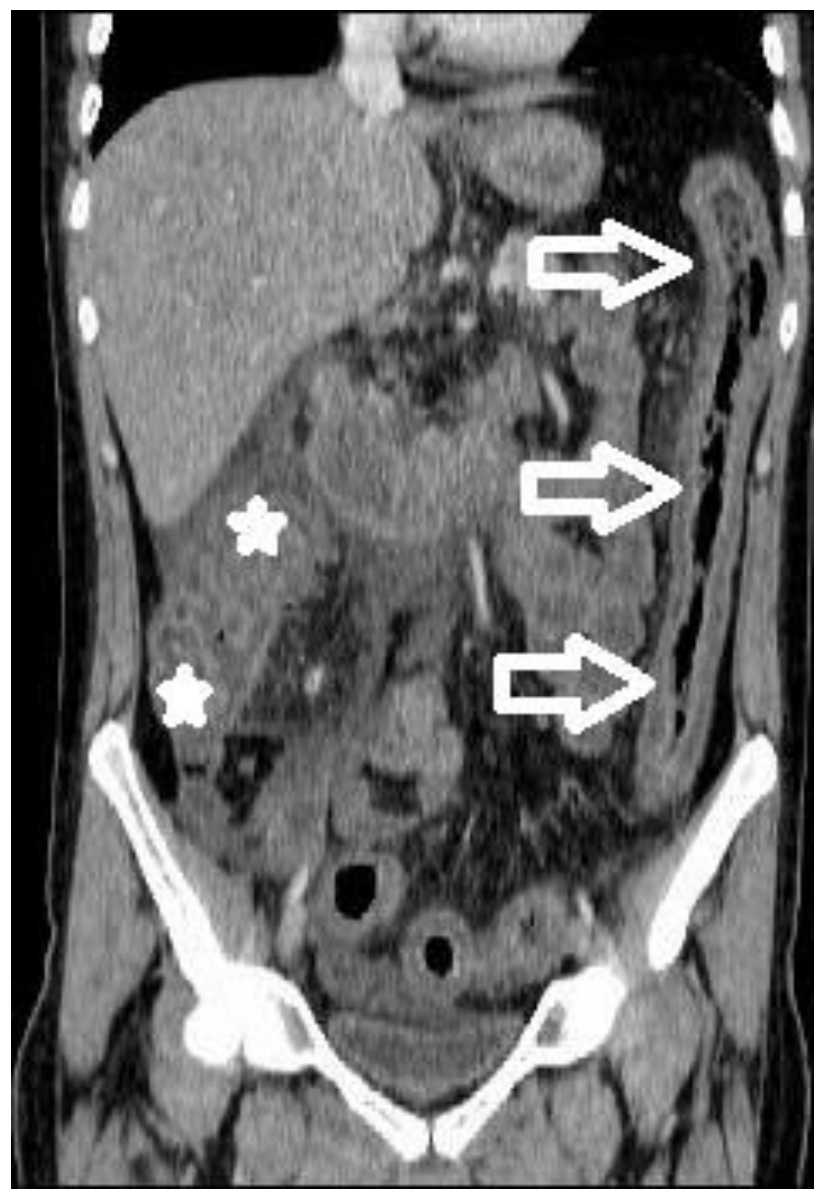

Fig. 3. Widespread thickening is observed in the ascending (stars) and descending colon (arrows) in coronal reformat image

clustered distended bowel loops in the right lower quadrant can be observed $(8,15)$. Barium x-ray and colonoscopy are contraindicated due to the possible risk of perforation (7).

Ultrasonography (US) findings are useful in patients supported by clinical findings. It can be used especially in the follow-up of pediatric patients due to its lack of radiation. US examination may show a decrease in intestinal peristalsis in the lower right quadrant of the abdomen, thickening of the intestinal wall, dilatation in the cecum, mass appearance, pericecal inflammation and free fluid. In ultrasonography with colored doppler, an increase in vascularity can be observed in the mucosa and in the intestinal wall. In severe cases, the cecum wall thickness is over $1 \mathrm{~cm}(16)$.

The most useful radiological method in the diagnosis of NE is oral and intravenous contrast abdominal CT. Normally, in the CT, the colon wall thickness is maximum $3 \mathrm{~mm}$ and the colon wall cannot be clearly selected due to the content or distention due to liquid-oral contrast. Pericolonic mesentery is homogeneous. The most common CT finding in NE is intestinal wall thickening. Intestinal distension, an

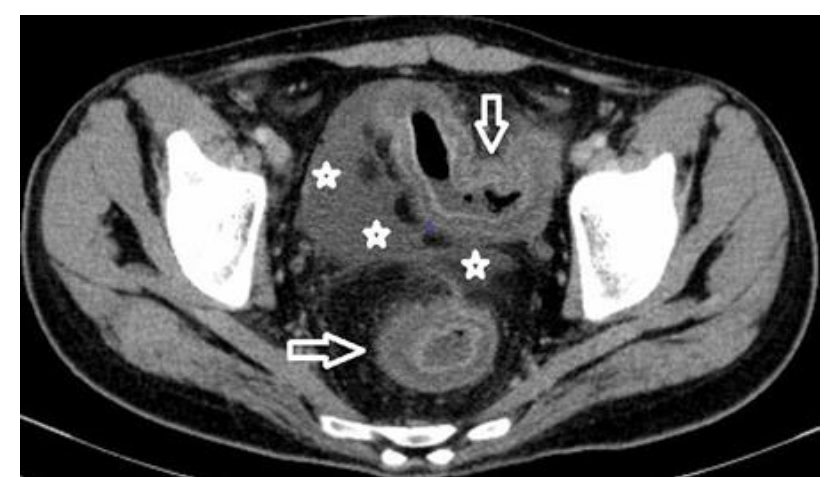

Fig. 4. Axial image shows wall thickening in the sigmoid colon (vertical arrow) and rectum (horizontal arrow). There is also free fluid and contamination in the adjacent mesentery (stars)

increase in mucosal enhancement, submucosal edema and pneumatosis coli can be observed. Inflammatory contamination-heterogeneity and related secondary mesenteric stranding appearance are common in the surrounding mesentery. Mesenteric LAP and free fluid can be monitored (8). The cecum and the right column can be affected in almost all cases, and the terminal ileum, transverse and left column segments can be affected at different rates (7). Complications such as pneumoperitoneum, pericolonic fluid collection and abscess can develop, and these complications can be easily observed with CT (17).

Although no complications were observed in the CT examinations of our patient group, there were other findings described above. Intestinal wall thickening in all patients was $11 \mathrm{~mm}$ and above. There are various findings and opinions that support the importance of intestinal wall thickness in terms of diagnosis and prognosis $(18,19)$. Colon wall thickening suggests the need for surgical treatment and affects the prognosis (20). The reported mortality rates for NE are up to $50 \%$, especially if the patient has transmural inflammation or intestinal perforation (21). In a US study of NE patients, Cartoni et al reported a $60 \%$ mortality in those patients with an intestinal wall thickness of $10 \mathrm{~mm}$ and above, and a $4.2 \%$ mortality in those with less than $10 \mathrm{~mm}$ (22). However, early recognition and good management of NE improves prognosis as seen in case-controlled studies $(3,10)$. In a recent study, the mortality rate in intensive care units was $32.1 \%$ and hospital mortality was $38.8 \%$ (10). Dorantes et al. in their study, which included 117 patients, $75 \%$ of whom had leukemia, they detected $\mathrm{NE}$ in 8 patients, all of whom had leukemia. Three of these patients deceased (37.5\%). They found no relationship between the severity of neutropenia and NE development and NE-related mortality (23). The mortality rate in our patient group was $60 \%(9 / 15)$, and of the exitus patients, 8 had leukemia, one had lung cancer. We did not find a relationship between 
Table 1. Patient information and intestinal involvement findings

\begin{tabular}{lcccccc}
\hline Patients & Age & Gender & $\begin{array}{l}\text { Affected intestinal } \\
\text { segments }\end{array}$ & $\begin{array}{c}\text { Intestinal wall } \\
\text { thickness (mm) }\end{array}$ & $\begin{array}{l}\text { Surviving } \\
\text { patients }\end{array}$ & $\begin{array}{l}\text { Exitus } \\
\text { patients }\end{array}$ \\
1 & 55 & M & A & 18 & & + \\
2 & 64 & M & A & 26 & & + \\
3 & 8 & M & A & 25 & + \\
4 & 19 & M & A & 11 & + & + \\
5 & 60 & M & A & 24 & + & + \\
6 & 46 & F & B & 13 & + & + \\
7 & 56 & M & C & 25 & + \\
8 & 50 & F & C & 30 & + \\
9 & 34 & M & C & 30 & + \\
10 & 48 & M & C & 15 & + \\
11 & 1 & F & C & 11 & + \\
12 & 33 & F & D & 18 & + \\
13 & 63 & F & D & 20 & + & + \\
14 & 24 & M & D & 18 & + & + \\
15 & 17 & M & D & 17 & + & + \\
\hline
\end{tabular}

A: Patients with only right colon involvement.

B: Patients with only right colon and left colon involvement.

C: Patients with only right colon and terminal ileum involvement.

D: Patients with right colon, left colon and terminal ileum involvement.

F: Female

M: Male

Table 2. Descriptive statistics and comparisons related to wall thickness ( $\mathrm{mm}$ ) in surviving and exitus patients

\begin{tabular}{lccccc}
\hline Groups & Mean & $\begin{array}{l}\text { Stdandard } \\
\text { Deviation }\end{array}$ & Minimum & Maximum & p \\
\hline $\begin{array}{l}\text { Surviving } \\
\text { patients }\end{array}$ & 15.67 & 5.05 & 11.00 & 24.00 & 0.018 \\
$\begin{array}{l}\text { Exitus } \\
\text { patients }\end{array}$ & 22.89 & 5.53 & 15.00 & 30.00 & \\
\hline
\end{tabular}

the severity of neutropenia and mortality. All patients had cecum and ascending colon, ie right colon involvement. The detection of additional left colon involvement in 2 of the deceased patients and additional terminal ileum involvement in 6 may make additional terminal ileum involvement more important in terms of poor prognosis.

The limitations of our study are that it is retrospective, the number of patients is small, and there is no histopathological diagnosis of the patients.

In conclusion, we obtained detailed information in determining intestinal involvement, the length of the affected intestine segment and mesenteric involvement with contrasted abdominal CT. Assuming that the cecum and right colon are affected in almost all cases, we found that the mortality rate increased in the additional terminal ileum involvement rather than the additional left colon involvement. This finding should be confirmed by studies with a high number of cases.

\section{References}

1. Davila ML. Neutropenic enterocolitis. Curr Treat Options Gastroenterol 2006; 9: 249-255.

2. Hsu TF, Huang HH, Yen DH, Kao WF, Chen JD, Wang LM, et al. ED presentation of neutropenic enterocolitis in adult patients with acute leukemia. Am J Emerg Med 2004; 22: 276279. 
3. Moran H, Yaniv I, Ashkenazi S, Schwartz M, Fisher S, Levy I. Risk factors for typhlitis in pediatric patients with cancer. J Pediatr Hematol Oncol 2009; 31: 630-634.

4. Portugal R, Nucci M. Typhlitis (neutropenic enterocolitis) in patients with acute leukemia: a review. Expert Rev Hematol 2017; 10: 169-174.

5. Pelletier JH, Nagaraj S, Gbadegesin R, Wigfall D, McGann KA, Foreman J. Neutropenic enterocolitis (typhlitis) in a pediatric renal transplant patient. A case report and review of the literature. Pediatr Transplant 2017; 21: e13022.

6. Chow EJ, Bishop KD. Painless neutropenic enterocolitis in a patient undergoing chemotherapy. Curr Oncol 2016; 23: e514-516.

7. Sachak T, Arnold MA, Naini BV, Graham RP, Shah SS, Cruis M, et al. Neutropenic Enterocolitis: New Insights Into a Deadly Entity. Am J Surg Pathol 2015; 39: 1635-1642.

8. Rodrigues FG, Dasilva G, Wexner SD. Neutropenic enterocolitis. World J Gastroenterol 2017; 23: 42-47.

9. Mourad N, Michel RP, Marcus VA. Pathology of Gastrointestinal and Liver Complications of Hematopoietic Stem Cell Transplantation. Arch Pathol Lab Med 2019; 143: 1131-1143.

10. Duceau B, Picard M, Pirracchio R, Wanquet A, Pène F, Merceron S, et al. Neutropenic Enterocolitis in Critically III Patients: Spectrum of the Disease and Risk of Invasive Fungal Disease. Crit Care Med 2019; 47: 668-676.

11. Bagnoli P, Castagna L, Cozzaglio L, Rossetti C, Quagliuolo V, Zago M, et al. Neutropenic enterocolitis: is there a right timing for surgery? Assessment of a clinical case. Tumori 2007; 93: 608-610.

12. Bierman HR, Amronin G. The ileocecal syndrome in the leukopathic conditions. Clin Res 1960; 8:134

13. Yuluğkural Z, Üçkardeş H, Mutlu B, Hacıhanefioğlu A. Nötropenik enterokolit: olgu sunumu. Balkan Med J 2007; 24: 162-164.
14. Robaday S, Kerleau JM, Tapon E, Levesque H, Marie I. Typhlitis: report of a case and review of the literature. Rev Med Interne 2008; 29: 224-227.

15. Vogel MN, Goeppert B, Maksimovic O, Brodoefel H, Faul C, Claussen CD, et al. CT features of neutropenic enterocolitis in adult patients with hematological disease undergoing chemotherapy. Rofo 2010; 182: 1076-1081.

16. Tamburrini S, Setola FR, Belfiore MP, Saturnino PP, Della Casa MG, Sarti G, et al. Ultrasound diagnosis of typhlitis. J Ultrasound 2019; 22: 103106

17. Patel JD, Gale HI, Chang KJ. Imaging of Large Bowel with Multidetector Row CT. Multislice CT 2019; 641-665.

18. Davila ML. Neutropenic enterocolitis: current issues in diagnosis and management. Curr Infect Dis Rep 2007; 9: 116-120.

19. Dietrich CF, Hermann S, Klein S, Braden B. Sonographic signs of neutropenic enterocolitis. World J Gastroenterol 2006; 12: 1397-1402.

20. Cardona Zorrilla AF, Reveiz Herault L, Casasbuenas A, Aponte DM, Ramos PL. Systematic review of case reports concerning adults suffering from neutropenic enterocolitis. Clin Transl Oncol 2006; 8: 31-38.

21. Gorschlüter M, Mey U, Strehl J, Ziske C, Schepke M, Schmidt-Wolf IG, et al. Neutropenic enterocolitis in adults: systematic analysis of evidence quality. Eur J Haematol 2005; 75: 1-13.

22. Cartoni C, Dragoni F, Micozzi A, Pescarmona E, Mecarocci S, Chirletti P, et al. Neutropenic enterocolitis in patients with acute leukemia: prognostic significance of bowel wall thickening detected by ultrasonography. J Clin Oncol 2001; 19: 756-761.

23. Dorantes-Díaz D, Garza-Sánchez J, CancinoLópez JA, Rocha-Ramírez JL, Rojas-Illanes FM, Parrado-Montaño JW, et al. Prevalence of neutropenic enterocolitis in adults with severe neutropenia and associated mortality. Rev Gastroenterol Mex 2009; 74: 224-229. 